\title{
ALTERAÇÕES DO COTIDIANO PROFISSIONAL E SOCIAL DE MÃES DE CRIANÇAS PORTADORAS DE NECESSIDADES ESPECIAIS
}

\section{Ana Vitória dos Santos Menezes ${ }^{1}$; Érika Tatiane de Almeida Fernandes Rodrigues²; Samea Marine Pimentel Verga ${ }^{3}$}

${ }^{1}$ Graduando de Bacharelado em Enfermagem, Universidade Federal do Amapá (UNIFAP), Macapá, Amapá.

${ }^{2}$ Doutora em Ciências (USP), Universidade Federal do Amapá (UNIFAP), Macapá, Amapá.

${ }^{3}$ Doutoranda do Programa de Pós-graduação em Enfermagem, Universidade Federal do Paraná (PPGENF/UFPR); Mestre em ciências da Saúde (UNIFAP).

DOI: 10.47094/IICNNESP.2021/42

\section{RESUMO}

Objetivos: Identificar alterações no cotidiano profissional e pessoal relatadas por mães de crianças diagnosticadas com autismo, Síndrome de Down e Paralisia Cerebral no estado do Amapá. Metodologia: Estudo descritivo, abordagem qualitativa, realizado através da análise de 36 entrevistas semiestruturadas, realizadas de 2018 a 2019 com famílias de crianças assistidas em dois centros de apoio em Macapá-Ap. Resultados: Das 36 entrevistadas, 17 não pararam de trabalhar; 19 pararam de trabalhar, porém, destas, 3 não relacionaram à criança. É perceptível entre as mães que deixaram de trabalhar a dedicação exclusiva para a criança e entre as mães que ainda trabalham, a adequação da rotina familiar para manter a rotina da criança. Conclusão: Pode-se perceber que as mães precisaram, em maior ou menor grau, se adequar e ou abdicar da vida laboral para cuidar e manter a rotina de cuidados da criança.

PALAVRAS-CHAVE: Família. Necessidades especiais. Trabalho ÁREA TEMÁTICA: Outros.

\section{INTRODUÇÃO}

Os primeiros anos de vida de uma criança constituem um momento crítico para seu desenvolvimento, uma criança com necessidades especiais necessita de estimulação precoce e diversos tratamentos e acompanhamentos para que consiga ter o desenvolvimento considerado adequado para o tipo de condição que possua (BENEVIDE et al., 2020). Logo, em alguns casos, a rotina do responsável por acompanhar a criança em seus atendimentos e tratamentos passa a ser limitada aos cuidados da criança e pode ocorrer de suas próprias vidas social e profissional ficarem em segundo plano. Assim, o objetivo do presente trabalho é identificar alterações no cotidiano profissional e pessoal das mães de crianças portadoras de necessidades especiais. 


\section{METODOLOGIA}

Trata-se de um estudo qualitativo, realizado com 36 familiares de crianças portadoras de necessidades especiais, assistidas no Centro Raimundo Nonato e na Associação de Pais e Amigos dos Excepcionais - APAE de um município do Amapá. A coleta ocorreu entre novembro de 2018 a março de 2019 através de entrevistas semiestruturadas cujos os dados foram submetidos à análise de conteúdo. Este estudo está em consonância com a Resolução n. 0466/2012 do Conselho Nacional de Saúde (CNS) /MS e foi aprovada pelo Comitê de Ética em Pesquisa sob o parecer consubstanciado n. 2.327.633.

\section{RESULTADOS E DISCUSSÕES}

Pode-se perceber que do total de 36 entrevistados, aproximadamente 47,3\% (16) dos participantes relataram que precisaram parar de trabalhar para cuidar da criança, nessa parcela é muito perceptível o relato de sentimento de estagnação da vida social, sentimento de solidão e sobrecarga, na qual a mãe fala que vive exclusivamente para cuidar da criança e que as demais atividades da sua vida ficam em último plano. Como podemos observar nas falas das entrevistadas:

“Às vezes eu me sinto sozinha, sozinha precisando de ajuda também, é..., a minha vida praticamente estagnou um pouco, porque eu tive que parar de sair, tive que parar de passear, quando eu tenho que passear e com ele, levar ele, é..., mudou muito mudou totalmente em todos os sentidos." (Mãe 02)

"Eu tive que abrir mão de tudo, tudo... Tive que abandonar meu emprego, praticamente eu falo pra todo mundo que eu deixei de viver, porque nada das minhas vontades prevalece, só as vontades dele". (Mãe 06)

Dos 17 participantes que não pararam de trabalhar, é perceptível que apesar de não terem tido que abdicar de sua vida profissional, as participantes relatam que a família precisa se programar muito bem e com antecedência para saídas de lazer ou até mesmo deixar de realizá-las, por conta do comportamento da criança ou por falta de tempo, já que a criança precisa de muitos cuidados e está com a rotina sempre cheia, assim como deixar de receber visitas de familiares e amigos, além de também relatarem o sentimento de estagnação da vida social. Como observado nas falas a seguir:

"A gente pensa muito antes de sair com ele, exceto em coisas básicas (...) às vezes eu nem levo ele na praça, nem no shopping, (...) ele não quer obedecer. (...) então a gente evita". (Mãe 11)

"Não gostava [a criança] de lugar com pessoas, ele não gostava de barulho, tinha um comportamento atípico, chamava assim atenção, tive que ficar, (...) eu ficava mais em casa porque não queria ninguém em casa, nem queria sair”. (Mãe 03).

\section{CONSIDERAÇÕES FINAIS}

A literatura aponta que frequentemente a mãe é a principal responsável pela rotina de cuidados da criança, sendo ela portadora de necessidades especiais ou não, logo é a mãe quem sofre mais impactos na vida profissional e pessoal, tendo que renunciar de outras áreas de sua vida, como lazer, vida social e relações afetivas (FREITAG et al., 2020). É apontado que muitas vezes a mulher exige de si mesma a obrigação e a responsabilidade de cuidar do filho, pois considera como uma 
necessidade intrinsecamente determinada e por sentir culpa pelo diagnóstico da criança, fora esses fatores, culturalmente é esperado que a mulher assuma a responsabilidade pelo cuidado dos filhos (PINTO et al., 2020).

Conclui-se que este estudo, assim como estudos similares, estabelece que é muito comum que a mãe precise adequar não só a sua rotina como também toda a estrutura de sua vida, para manter os cuidados da criança portadora de necessidades especiais, isso se deve a diversos fatores intrínsecos, como o sentimento de culpa pelo diagnóstico, e extrínsecos, como o estabelecimento cultural da responsabilidade do cuidados dos filhos pela mulher.

Nessa perspectiva, o apoio familiar vem a ser uma ferramenta estratégica que pode oferecer suporte e contribuir para o enfrentamento dessa nova condição que se apresenta como transformadora do cotidiano dessas mulheres (BENEVIDE et al., 2020). E não só a família pode atuar como estrutura para ajudar a mãe a desenvolver sua autonomia e permanecer com sua rotina e círculos sociais, mas também os profissionais de saúde, uma vez que compreendem a necessidade desse suporte construtivo. É importante que o profissional esteja ciente dos aspectos sociais, econômicos e culturais da família, a fim de se estabelecer não só os cuidados da criança como também dos pais, uma vez que podem adoecer no processo de continuidade do tratamento da criança e assim comprometer negativamente os cuidados à criança e consequentemente à família (FREITAG et al., 2020).

\section{PRINCIPAIS REFERENCIAS}

BENEVIDES, Carla Beatriz Lopes; et al,. Vivência de Mães com Filhos Diagnosticados com Síndrome de Down. São Paulo: Rev. Nursing ; 23(262): 3745-3750, abr.2020.

FREITAG, V.L., et al,. TORNAR-SE MÃE DE UMA CRIANÇA COM PARALISIA CEREBRAL: SENTIMENTOS VIVENCIADOS. Rio Grande do Sul: Psicologia Em Estudo, 25, 2020.

PINTO, Alinne Souza; CONSTANTINIDIS, Teresinha Cid. Revisão Integrativa sobre a Vivência de Mães de Crianças com Transtorno de Espectro Autista. Campo Grande: Rev. Psicol. Saúde, v. 12, n. 2, p. 89-103, ago. 2020. 